ISSN:

Print - $2277-0755$

Online - $2315-7453$

(c) FUNAAB 2015

\title{
CONTRIBUTION OF PERI-URBAN FORESTS TO NEIGHBOURHOOD LIVELIH OODS IN ABEOKUTA, OGUN STATE, NIGERIA
}

\author{
J.A. SOAGA, M. O.ADEDOKUN AND S. N. SEGBENU \\ D epartment of Forestry and Wildlife management, \\ Federal University of Agriculture, A beokuta, O gun State, Nigeria \\ *Corresponding author: soagaj@yahoo.com
}

\begin{abstract}
The study examined the contribution of peri-urban forest to neighbourhood livelihoods in Abeokuta, Ogun State, Nigeria. Stratified sampling technique was adopted for the study. Four strata representing different communities were selected; Ajegule, Ibode Olude, llugun Titun and Mawuko. From each stratum, twenty five respondents were randomly selected with a total of 100 respondents from the neighbourhood. Questionnaire was used as the instrument of data collection. The result showed that poverty line was N8,871.41 monthly and $41 \%$ of the respondents were categorised as poor (Poverty incidence). Household assets acquisition as poverty indicator showed that majority of the respondents could not afford luxury items such as cars (89\%), generators (71\%) and electric cookers (99\%). Livelihood activities identified in peri-urban forest with respondents distribution were firewood collection $24 \%$, wages $24 \%$, snail gathering $7 \%$, medicinal leaves collection $5 \%$, hunting $8 \%$, teak leaves collection $21 \%$ and geological materials extraction $11 \%$. The earnings and income shares by source indicated that forest contributed $17 \%$ of total income in Ajegunle, $15 \%$ in Ibode Olude, $18 \%$ in llugun Titun and $15 \%$ in Mawuko. This showed the contribution of peri-urban forest to welfare of the respondents in the neighbourhood. Consequently, it is recommended that conservation efforts must increase through forest policy for peri-urban forests coupled with adult literacy for adequate education to reduce dependence on forests in peri-urban areas to enable the forest impact positively through eco-services on the lives of residents in the locality.
\end{abstract}

Keywords: Livelihoods, Poverty, Household assets, Earnings and Income

\section{INTRODUCTION}

Forest being a very versatile environmental resource provides diverse goods and services. The goods are made up of raw materials and energy sources usually used by human beings as input into the production systems. These include: timber, fuel wood, poles, pulpwood, wood- based panels and other Non Timber Forest Products (NTFPs). The NTFPs include foods and drugs in the form of edible fruits, medicinal plants, wildlife and other products such as honey and edible mushroom. Despite the significance of forests to man, World Bank (1999) reported that more than $45 \%$ of 590 million people in sub-Sahara Africa live be- 
low poverty line of $\$ 1$ per day. A condition necessitating dependence on forests. Forest services can be viewed from two perspectives; social and environmental. The former consists of that part of the forest environment that provides ethnological services such as outdoor recreation, wildlife gaming and viewing, and space for spiritual activities. The latter borders primarily on the provision of life support requirement for human being (Nisbet, 1991).

Forests have the highest species diversity and endemism of any terrestrial ecosystem in the world (WCMC, 2000; WRI, 2000). Therefore in most developing countries, forests and its products contributed immensely to economic development because of large rural populations that depended on the natural resource for their livelihoods. According to Kaimowitz (2003), a large proportion of the population obtained their subsistence and cash income from diverse set of forest products and forest related activities. This was in addition to meeting the needs of the rural people for food and shelter. Bryon and Arnold (1997) noted that majority of rural households in developing countries and a large proportion of urban households depended on plant and animal products of the forests to meet part of their nutritional needs. However, the description of livelihood was clearly expressed by Chambers and Conway (1992) that livelihood as comprising the capabilities, assets and activities required for a means of living. Capabilities in this context refer to a person's ability to cope with stresses and shocks with the ability to find and make use of livelihood opportunities. Consequently, Scoones (1998) described assets as the basic material and social resources that people have in their possession. Therefore, activities refer to the ways in which capabilities and assets are combined to achieve liveli- hood outcomes. Forests within the neighbourhood provided the livelihoods in terms of benefits derived by the neighbours. Livelihood is considered sustainable when it can cope and recover from stresses and shocks, maintain its capabilities and assets, both now and in the future without undermining the natural resource base (Carney, 1998; DFID, 1999). Thus, peri-urban forests contributed to neighbourhood livelihoods. The objectives of this study therefore are to:

* describe the socio-economic characteristics of respondents in the neighborhood

* identify the various uses of peri-urban forest in the neighborhood

* determine the poverty line of the respondents and the contribution of forest income to total income

\section{METHODOLOGY}

\section{The study area}

The study was carried out in Abeokuta. Abeokuta is the State capital of O gun State, Nigeria and is located between Latitude $7^{0}$ $15 / \mathrm{N}$ and longitudes $3^{0} 25 / \mathrm{E} \quad-4037 / \mathrm{E}$. Abeokuta has two Local G overnment Council areas drawn along political divisionAbeokuta north and Abeokuta south. The area is situated in outlier of rainforest with annual rainfall of $100-150 \mathrm{~cm}$ (Awojuola, 2001 and O nakomaiya $\notin a \mathrm{al}$, 1992). The environment is characterized by two distinct seasons. The longer wet season last for eight months (March-O ctober) and the shorter dry season last for four months (NovemberFebruary). The relative humidity is high all year round, generally above $80 \%$ during the wet season and fluctuates between 60-80\% during the dry season. The most humid 
months coincide with the rainy season spanning between March and October. Humidity and the long wet season ensure adequate supply of water and continuous presence of moisture in the air. This trend promotes perennial tree growth. The soils in the area are dominated by clayey loam developed on underlying granite. There are also laterite soils. Abeokuta has extensive free forest areas with two gazetted forest reserves of $61.19 \mathrm{Km}^{2}$ land area. Major timber crops include Teak and Gmelina with other indigenous species.

The major occupation of the people in the study area is farming with agricultural crops such as cassava, maize, cocoyam, plantain, palm produce and vegetables. The area is also rich in fauna resources such as fish of various species, grasscutter, giant rat, grey rat, monitor lizard, weaver birds and others. Stone quarrying is also well developed. Major non-farm employments are provided by transportation and forestry activities such as timber exploitation, firewood, leaves collection and charcoal production.

\section{Data Collection}

D ata were collected through the administration of questionnaire to 100 respondents (pre-determined sampling frame) across the forest neighbourhood in Abeokuta using Stratified Random Sampling technique. The neighbourhood had four major settlements and each settlement represented a Stratum, they were Ajegunle, Ibode-Olude, IlugunTitun and Mawuko. Respondents were randomly selected from the four settlements and they cut across farmers, traders, arti- sans, civil servants and other knowledgeable members of the society. Information collected were demographic characteristics of respondents, forest activities and income from forest related activities.

\section{Data Analysis}

D ata from the survey were analysed using both descriptive and statistical inferential procedure. Poverty level was determined using Income level approach (D eaton, 1997) and household assets acquisition (PRB, 2003). The contribution of forestry to livelihoods was determined through earnings and total income shares by source.

\section{RE SULTS AND DISCUSSION Demographic characteristics of respondents}

Table 1 shows the result of the demographic characteristics of the respondents in the study area. Majority, (53\%) of the respondents were female and $47 \%$ male. Consequently, forest activities in the neighbourhood were female dominated. The age distribution showed that $42 \%$ were between the ages of $41-50$ years, followed by $38 \%$ for 31 - 40 years of age, while $16 \%$ of the respondents were between ages 21- 30 years. Only $3 \%$ were between ages 51- 61years and $1 \%$ between $61-70$ years. The table also shows that majority, (86\%) were married, $12 \%$ single and $2 \%$ widower.

The household size of the respondents ranged from 1 to 8 . Household size of 5 - 6 members recorded $44 \%$, followed by $3-4$ with $38 \%$, 1- 2 with $13 \%$ and $7-8$ with $5 \%$. 
On education, majority (52\%) of the respondents had no formal education, 25\% had Primary education, while $16 \%$ had Secondary education and only $7 \%$ of the respondents had Tertiary education. On ethnic distribution, majority $(90 \%)$ were Yoruba and they dominated the livelihood activities.

\section{Table 1: Demographic charactenistics of the respondents}

\begin{tabular}{|c|c|c|}
\hline Variables & Frequency & Pencentage \\
\hline \multicolumn{3}{|l|}{ Gender } \\
\hline Male & 47 & 47 \\
\hline Female & 53 & 53 \\
\hline Total & 100 & \\
\hline \multicolumn{3}{|l|}{ Ages (years) } \\
\hline $21-30$ & 16 & 16 \\
\hline $31-40$ & 38 & 38 \\
\hline $41-50$ & 42 & 42 \\
\hline $51-60$ & 3 & 3 \\
\hline $61-70$ & 1 & 1 \\
\hline Total & 100 & \\
\hline \multicolumn{3}{|l|}{ Marital Status } \\
\hline Single & 12 & 12 \\
\hline Married & 86 & 86 \\
\hline Divorced & 0 & 0 \\
\hline Widow(er) & 2 & 2 \\
\hline Total & 100 & \\
\hline \multicolumn{3}{|l|}{ Household Size } \\
\hline $1-2$ & 13 & 13 \\
\hline $3-4$ & 38 & 38 \\
\hline $5-6$ & 44 & 44 \\
\hline 7-8 & 5 & 5 \\
\hline Total & 100 & \\
\hline \multicolumn{3}{|c|}{ Educational Level of Respondents } \\
\hline Primary & 25 & 25 \\
\hline Secondary & 16 & 16 \\
\hline Tertiary & 7 & 7 \\
\hline No formal education & 52 & 52 \\
\hline Total & 100 & \\
\hline \multicolumn{3}{|l|}{ Tribe } \\
\hline Yoruba & 90 & 90 \\
\hline Igbo & 9 & 9 \\
\hline Hausa & 1 & 1 \\
\hline Total & 100 & 1 \\
\hline
\end{tabular}

Field survey, 2012 
CONTRIBUTION OF PERI-URBAN FORESTS TO NEIGHBOURHOOD LIVELIHOOD S IN.....

Poverty Line

Table 2: Poverty line using Income Level Approach

\begin{tabular}{llll}
\hline STEP 1 & STEP 2 & STEP 3 & STEP 4 \\
\hline $\begin{array}{l}\text { Sorting income by } \\
\text { level } \\
1774880.7\end{array}$ & The mean of Income & $\begin{array}{l}\text { The percentage of } \\
\text { mean selected } \\
\text { Percentage } 0.5\end{array}$ & The poverty line \\
\hline
\end{tabular}

Poverty Line $=$ Total Mean Income $\times$ Convenient Percentage Chosen

$$
=17748.81 \times 0.5=\mathrm{N} 8,874.41 \text { Monthly }
$$

\section{Household Asset Procurement}

The quality of life as measured by acquisition of household assets is presented in Table 3. The result shows that majority (98\%), owned bicycles, radio (95\%), kerosene stove $(93 \%)$, and television $(67 \%)$ accounted for the most predominant household assets owned by the respondents. These items were very important to the respondents. Bicycle, radio, kerosene stoves and television sets were considered as items commonly used by the poor. Majority of the respondents do not own luxury items such as Cars (owned by only $11 \%$ of the respondents), Electrical generators (29\%), Motorcycles $(72 \%)$ and Gas Cooker (1\%) which shows that majority of the respondents were actually poor. This study is in line with the findings of Etim and Edet (2014) that noted the accumulation of asset as an important means by which people move out of poverty and improve their livelihood, therefore, the social status of people changes with more luxury assets (Mckay, 2009). Carter and barret (2006) reported that people lacking assets risk being caught in poverty trap.

Table 3: Household assets of respondents

\begin{tabular}{lcll}
\hline ASSET & YES & NO & TOTAL \\
\hline Car & 11 & 89 & \\
Motorcycle & 28 & 72 & 100 \\
Television & 67 & 33 & 100 \\
Electrical G enerator & 29 & 71 & 100 \\
Bicycle & 98 & 2 & 100 \\
Settee & 38 & 62 & 100 \\
Radio & 95 & 5 & 100 \\
Gas Cooker & 1 & 99 & 100 \\
Rug/ Carpet & 59 & 41 & 100 \\
Kerosene Stove & 93 & 7 & 100 \\
\end{tabular}

Field survey, 2012 
Distribution of Respondents Based on highest percentage of $24 \%$ each, followed by Livelihood Activities

leaves collection $21 \%$, geological material Table 4 shows the distribution of respon- (sand and gravel) collection 11\%, hunting dents based on the livelihood activities in 8\%, snail gathering $7 \%$ and medicinal plant the study area. The table shows that firecollection $5 \%$. wood collection and wages recorded the

Table 4: Benefits of forest reserve to respondents

\begin{tabular}{lcc}
\hline ACTIVITY & FREQUENCY & PERCENTAGE \\
\hline Firewood collection & 24 & 24 \\
Snail Gathering & 7 & 7 \\
Medicinal plants collection & 5 & 5 \\
Leaves collection & 21 & 21 \\
Wages & 24 & 24 \\
Hunting & 8 & 8 \\
Geological materials & 11 & 11 \\
Total & 100 & 100 \\
\hline
\end{tabular}

Field survey, 2012

Eamings and Income Shares by Source and location

Table 5 shows the earnings and income shares by source on stratum basis. The result indicates income diversification among the respondents. Income source shows high earnings in wages. The contribution of various activities (firewood collection, snail gathering, medicinal plants, leaves collection, hunting activities, geological material) to livelihoods was highlighted. Arnold (1998) examined the contribution of forests to sustainable livelihoods and noted that forests contribute to income, food security, reduced vulnerability, increased welfare and sustainable use of natural resource base. The findings from Arakanga forest reserve is in line with Arnold (1998). In Ajegunle settlement, the forest contributes $17 \%$ to total income, in Ibode-Olude it contributes 15\%. Also in Ilugun-Titun of total income, it contributes 18\% and in Mawuko 15\%. Wages contribute 58\% in Ajegunle, $63 \%$ in IbodeOlude, $57 \%$ in Ilugun-Titun and $63 \%$ in Mawuko. Also, Geological material contributes $25 \%$ in Ajegunle, $22 \%$ in Ibode-Olude, $25 \%$ in Ilugun-Titun and 23\% in Mawuko. Wages recoreded the highest contribution to total income. 
CONTRIBUTION OF PERI-URBAN FORESTS TO NEIGHBOURHOOD LIVELIHOODS IN.....

Table 5: Eamings and Income source by Shares and location

\begin{tabular}{llll}
\hline Location & Forest & Wages & Geological material \\
\hline Eamings per location & & & \\
Ajegunle (N=25) & 0.23 & 0.22 & 0.24 \\
Ibode-Olude (N=25) & 0.25 & 0.27 & 0.24 \\
Ilugun-Titun (N=25) & 0.25 & 0.21 & 0.24 \\
Mawuko (N=25) & 0.27 & 0.30 & 0.28 \\
Total Income of respondents & & & \\
Ajegunle (N=25) & 0.17 & 0.58 & 0.25 \\
Ibode-Olude (N=25) & 0.15 & 0.63 & 0.22 \\
Ilugun-Titun (N=25) & 0.18 & 0.57 & 0.25 \\
Mawuko (N=25) & 0.15 & 0.63 & 0.23 \\
\hline
\end{tabular}

Field survey, 2012

\section{CONCLUSION}

The study has taken an exploratory look into the contribution of Arakanga Forest Reserve to livelihoods in Abeokuta, Ogun State. The data from this study were evaluated using Income level method according to Deaton (1997). The estimated poverty line of the respondents was N8,874.41 with $41 \%$ respondents living below the poverty line. This implies poverty incidence level indicating the poor in the study area. The household assets recorded also shows that luxury items such as cars, electrical generators and gas cookers were few among the respondents. The study also revealed that Arakanga Forest Reserve was important to the livelihood of the people living around the reserve. It must also be understood that Arakanga Forest Reserve provided a multiplicity of goods and services in the neighbourhood (firewood, leaves, snail, medicinal plants, hunted animals and others). Consequently, the forest provided diversified sources of income as well as wages by staff of the reserve and income from geological material such as sand and gravel. However, it is clear from the study that there were poor respondents residing in neighbourhood communities surrounding Arakanga Forest Reserve. Forests have historical record of influencing economic welfare and contributing to economic development. Therefore, the periurban forest is equally playing a major role by contributing to the livelihood of the people.in the study area. In view of the significance of the forest, it is suggested that policy instrument should be used to improve conservation effort in the reserve for sustainability and adult literacy education should be encouraged among respondents to reduce 
dependence on the available forest resources to promote non market benefits and improve the lives of people living in the area positively.

\section{REFERENCES}

Awojuola, E. 2001. Ogun State Investors Guide. Eni-Meg Nigeria Ltd. In collaboration with $\mathrm{O}$ gun State Ministry of Industries and Social D evelopment. Ogun State, Nigeria

Amold, J. E.M. 1998. Forestry and sustainable rural livelihoods. In. D. carney (ed). Sustainable rural livelihoods: What contribution can we make? London, UK D epartment for International D evelopment.

Bryon, N. and Amold, J. E. M. 1997. What future for the people of the Tropical forests? CIFOR Working Paper No 19. Centre for International Forestry Research (CIFO R), Indonesia.

Chambers, R. and Conway, G. 1992. Sustainable rural livelihoods: practical concepts for the $21^{\text {st }}$ century. Discussion Paper 296. Institute of D evelopment Studies, Brighton.

Camey, D. 1998. Implementing the sustainable rural livelihoods approach. In. Carney, D. (ed.) Sustainable rural livelihoods: What contribution can we make? London, UK D epartment for International D evelopment.

Carter, M.R., and Barret, C.B. 2006. The economics of poverty trap and persistent poverty: An asset-based approach. Journal of D evelopment Studies 42(2):178-199

Deaton, A. 1997. The Analysis of Household Surveys. The John Hopkins University
Press, Baltimore, USA.

DFID, 1999. D epartment For International D evelopment. Sustainable Guidance Sheets report: Framework. London, UK D epartment for International D evelopment, London.

Etim, N., and Edet, G. 2014. Does asset ownership reduce chronic poverty? European SaientificJaumal 10 (1): 168-176

Kaimowitz, D. 2003. Not by bread alone. Forests and rural livelihoods in sub Saharan Africa. In: O ksanen, T., Pajari, B and Toumasjukka, T (eds). Forests in Poverty Reduction Strategies: capturing the Potential. European forest Institute, Joensuu, Finland.

Mckay, A. 2009. Assets and chronic poverty: Background paper. Working paper No 100. Chronic Poverty Research Centre. University of Sussex, Brighton, UK.

Nisbet, E. O. 1991. Leaving Eden - to protect and manage the earth. Cambridge University Press, Cambridge, UK. 358p

Onakomaiya, S.0., Oyesiku, K. and Judge, F .J. 1992. O gun State in Maps. Rex Charles Publication. O yo State, Nigeria.

PRB, 2003. Population Reference Bureau. World Population D ata Sheet-D emographic data and estimates for the countries and regions of the World, Connecticut Ave, NW Washington, D.C, USA.

Scoones, I. 1998. Sustainable rural livelihoods: A framework for analysis. Working Paper 72. Institute for Development Studies, Brighton. UK

WCMC 2000. World Conservation Moni- 
CONTRIBUTION OF PERI-URBAN FORESTS TO NEIGHBOURHOOD LIVELIHOODS IN.....

toring Centre. Global Diversity In: Report 2009: A Development Emergency. Groombridge, B., and Jenkins, M. D . (eds.) The World Bank, Washington, D .C. USA.

Earth's living resources in 21st century.

World Conservation Press, Cambridge, WRI, 2000. World Resources Institute. UK. World resources 2000-2001: People and

World Bank 2009a. Global Monitoring ington, D.C. World Resources Institute

(Manuscipt reecived 20thMarch, 2013; accepted 1st Sqtember, 2015) 